\title{
Challenges for a Transition from Peasant Agriculture to a Business Agriculture in Burkina Faso
}

\author{
Babou Sogue, Handan Akcaoz*
}

Department of Agricultural Economics, Faculty of Agriculture, Akdeniz University, 07070 Antalya, Turkey

\begin{tabular}{l} 
A R T I C L E I N F O \\
Research Article \\
Received 19 September 2017 \\
Accepted 27 December 2017 \\
\hline
\end{tabular}

Keywords:

Family farming

Burkina Faso

Corporate agriculture

Agricultural finance

Exegetical method \begin{abstract}
A B S T R A C T
Since the national farmers' day on May 12, 2017 in Kaya, Burkina Faso, the debate on agriculture has been to establish the agricultural entrepreneurship through the concept of agriculture as a family business (ACEF). And it is from this perspective that this study was conducted to analyse the financing possibilities open to family farming and to deduce the constraints of the transition from family farming to enterprise farming. To do this, we used the exegetical method to characterize the existing agricultural formations, to identify the means of financing and the constraints of the agricultural transition. The agricultural sector is strongly dominated by family farming with low physical and financial capital. The means of financing are self-financing and external financing. However, the transition will not be without problems because there are technical and political constraints to overcome.
\end{abstract}

*Corresponding Author:

E-mail: hvurus@akdeniz.edu.tr

DOI: https://doi.org/10.24925/turjaf.v6i7.812-819.1554

\section{Introduction}

Agricultural and rural finance is an important component of the development strategies adopted by the countries of the South since the late 1950s until the advent of the Structural Adjustment Programs (SAPs). This funding was mainly provided in Burkina Faso by public funds and non-governmental organizations (NGOs) acting through the Economic Interest Groups (GICs). The latter, under the control of Burkina Faso's governments, acted as intermediaries between farmers and donors and were supposed to collect donors' funds and channel them to their members. The marked intervention of the State, especially at the time of the National Council of the Revolution, in cooperative organizations (Godet, 1994) and its providential role was to allow the popularization of new techniques and the rationalization of working methods in order to move away from the specter of famine from the great drought of the 1970s. This approach was effective in demonstrating the achievement of food self-sufficiency and catalyzing the growth of national agricultural production through them.

But the liberalization of the agricultural sector on the SAPs has dismantled agricultural public credit lines and led to the scarcity of agricultural credit (Wampfler and Lapenu, 2002). Everything that has stifled the beginnings of agricultural productivity gains. Indeed, the process of economic and financial liberalization led to the restructuring of agricultural and development banks and led to the total closure of most of them. According to Niyongabo (2008) before the 1990s SAPs, each country in the West African Economic and Monetary Union (WAEMU) had an agricultural bank and a development bank. As a result of the adjustment, of only 14 banks, only 3 agricultural banks and one development bank survived and developed. These banks had accumulated unpaid debts that eventually absorbed their own funds through the implementation of provisions and caused their bankruptcy (Lesaffre, 2000). In addition, Burkina Faso's only agricultural bank, known as the National Agricultural and Commercial Bank of Burkina Faso (BACB), was privatized in August 2008 and taken over by the commercial bank Ecobank-Burkina, Ecobank Transnational Incorporated subsidiary (Ouestafnews, 2009).

Moreover, commercial banks are weakly involved in agricultural and rural finance because of the lack of control over agricultural risks, poor knowledge of the rural environment, priority to cash crops, lack of longterm resources, lack of guarantees, etc. This explains why 
only $14 \%$ of the total credit supply goes to the agricultural sector of the WAEMU countries (Lesaffre, 2000). According to the same author, these are mainly short-term campaign credits, most of which are provided by commercial banks $(92 \%)$, compared with only $5 \%$ for development banks.

Given the low level of private financing, the State had reversed itself around 1995 by the option of the agribusiness men and also realized a large part of investment by the development of supermarkets near the dams on which will be of agricultural developers. Among them are the Sourou students, cotton pilot producers, FLEX FASO, etc. To these players of the means of production will be granted, the sale of their production will be ensured by the new Society of Promotion of the Agricultural Sectors (SOPROFA). While the results are satisfactory for cotton, the same is not true for rice due to the lack of interest of young people in agriculture, the lack of follow-up after their installation and an internal market saturated with imported rice.

\section{Context}

These efforts to popularize cash crop farming will penalize the family supplying the essential food of the country. Thus, the country will experience a series of food crises in the 2000s, the most important of which was in 2008. The latter prompted the Burkina Faso State to revise its policy of public financing of agriculture by injecting in 2008, 5 billion FCFA to support agricultural production in general and that of rice in particular. This amount was doubled in 2009. In 2010, all of these shares amounted to about CFAF 7 billion (Ouedraogo et al., 2011). The Table 1 summarizes government support for agriculture to alleviate the food crisis.

According to the Burkina Faso (2017) initiatives were taken to create a real agricultural bank with a capital of 15 billion FCFA. The share capital should be fully paid up by May 30, 2017 to allow for the holding of the General Meeting required to finalize the application for approval.

Table 1 Government support to agriculture from 2008 to 2016

\begin{tabular}{|c|c|c|c|c|c|c|}
\hline Years & $\begin{array}{l}\text { Fertilizer } \\
\text { (tons) }\end{array}$ & $\begin{array}{l}\text { Improved seed } \\
\text { (tons) }\end{array}$ & $\begin{array}{c}\text { Organic manure } \\
\text { (tons) }\end{array}$ & $\begin{array}{l}\text { Tractors } \\
\text { (units) }\end{array}$ & $\begin{array}{l}\text { Plows } \\
\text { (units) }\end{array}$ & $\begin{array}{l}\text { Draft oxen } \\
\text { (units) }\end{array}$ \\
\hline 2008 & 10.000 & 7.055 & 14.000 .000 & 700 & 100.000 & \\
\hline 2009 & 233.175 & 7.297 & 7.000 .000 & & & \\
\hline 2010 & 16.541 & 9.068 & 8.040 .553 & & & \\
\hline 2011 & 15.073 & 14.224 & 8.190 .452 & & & \\
\hline 2012 & 18.725 & 5.889 & 560.289 & & & \\
\hline 2013 & 8.976 & 9.009 & 2.169 .517 & & & \\
\hline 2014 & 8.161 & 7.419 & & & & \\
\hline 2015 & 12.550 & 3.900 & 1.393 .500 & & 14.939 & 3.601 \\
\hline 2016 & 26.000 & 7.000 & & & & 4.820 \\
\hline
\end{tabular}

Despite the official public support initiatives for agricultural finance, there is a currency bottleneck. Indeed, the CFA Franc is a fixed currency arithmetic to the Euro since 1944 used by 8 countries of the WAEMU zone that each country is required to have a fiscal policy in order to maintain monetary stability. As a result, governments are more concerned about the inflationary effects of a debt economy at the expense of investment and job creation to meet the monetary clauses. This is why traditional banks give credit to farmers' organizations at a rate of $12 \%$, while the average rate of inflation is less than $3 \%$, which is still subject to value added tax of $18 \%$ (Ouédraogo, 2010). Nubukpo (2017) points out that "currency has an impact on production via credit. The current Franc area is a monetary repression area with a credit-to-GDP ratio of $23 \%$, compared with $100 \%$ in the euro area and $150 \%$ in South Africa. In other words, credit in the Franc area is insufficient to stimulate the structural transformation of the economies of this zone, either because access is impossible, especially in rural areas, interest rates are prohibitive for private operators. Finally, because the states have tied their hands by accepting that the central banks of the zone no longer directly finance them (since September 2002 for the WAEMU states). As a result, while central bank interest rates are around $2.5 \%$ in the Franc area, governments borrow more than $6.5 \%$ on the financial market, representing a net charge of 4 percentage points".
The long period of disengagement from the public sector in agricultural financing and the negative impact of the existing monetary system has given rise to a system of financing that is moribund and inadequate to the agricultural reality. This has resulted in low investment or even disinvestment on the farm, which is incapable of boosting economic development. The corollary of the conjugate elements is the domination to this day of small family farms confronted with important climatic hazards and depend mainly on the exploitation of natural resources which are experiencing a process of degradation (Touré and Seck, 2005). For some, this precarious situation of agriculture is partly due to its non-performing and non-market oriented family form. It is now time to move towards corporate agriculture.

Since then, on May 12, 2017, Action for the Promotion of Local Initiatives (APIL) is considering the establishment of the agricultural entrepreneurial spirit through the concept of "Agriculture as a Family Enterprise (ACEF)" as a new approach to agriculture that aims to increase net income of its actors by making agriculture a real undertaking. More specifically, it seeks to develop entrepreneurial spirit in farms and livestock farms, to find ways of reducing production costs, to identify ways of adding value to crops and to give to improve marketing, that is to say the marketing of their products. Such an approach is only feasible through the 
introduction of a new system of public and credit financing with low interest rates, which would undoubtedly increase the efficiency of government support for the production effort (Ouédraogo, 2010).

The objective of this study is to analyse the financing possibilities available to Burkina Faso family agriculture, to deduce the constraints and define the perspectives.

\section{Techniques and Methods}

In our research we used the following the exegetical methods. The exegetical method is a method of interpretation of texts generally used in law. This method is based on the exegesis of existing documents on family and entrepreneurial agriculture in general and in particular that of Burkina Faso. It aims to characterize family farming and enterprise in the world. Secondly, it aims to highlight the opportunities and constraints that Burkina Faso's agriculture faces for a transition to a business agriculture. Exegesis can be defined by three propositions:

When the opportunity clearly exists, it must be exploited. In other words, exegesis intervenes only if the opportunity is obscure.

When the opportunity is obscure, it becomes a constraint to be clarified to allow the operations of mutation of family farming. We must seek appropriate solutions.

If the opportunity is absent then it must be proposed.

In the case of the exegetical method, we admit that the interpretation is creative solutions. This interpretation comes in the case of sufficient information to act in an economic sector for stakeholders.

So the exegetical method will allow us to characterize the existing agricultural formations, to identify constraints to the transition and agricultural financing in Burkina Faso. The documentary technique will be used in the consultation of the reports of various public services as private interested in the question that is the subject of our research.

\section{The Foreign Exchange Premium}

Given that the value of money plays an important role in the competitiveness of agricultural commodity prices, we will briefly recall the calculation of the real exchange rate. Generally, countries that face sustained demand for their products on world markets float their currencies and their values are determined by supply and demand. Countries with currencies that do not face such strong demand often fix their currencies against a basket of currencies.

The foreign exchange premium is a premium for traded goods which can be positive or negative and occurs when the currency is overvalued or undervalued in relation to other countries' currencies.

(Willingness to pay for traded items)/Willingness to pay for non-traded items

We convert the foreign exchange price: (C.I.F. or F.O.B.). Into domestic currency at the official exchange rate and then multiply by, $1+$ the foreign exchange premium.
But, when the country exchanges with many other countries the bilateral exchange rate is no longer sufficient to reflect the reality of international competition. It is then necessary to calculate the real exchange rate.

\section{Measuring the Real Exchange Rate}

The real exchange rate is a synthetic measure of the evolution of a country's competitiveness with the rest of the world. The real effective exchange rate $\lambda p$ always combines a nominal exchange rate index and two price indices:

$$
\lambda_{P}=E \cdot \frac{P *}{P}
$$

$\mathrm{E}$ is the weighted average of bilateral exchange rates. It is the nominal effective exchange rate; $\mathrm{P}$ and $\mathrm{P}^{*}$ are the price indexes of the local and foreign economy. $\mathrm{P}^{*}$ is a weighted average of prevailing prices in as many of the trading partner countries as possible in the local economy. Let us suppose that Burkina Faso exchanges with n Asian countries each having a "weight" $\alpha i \%$ in the international exchanges of the local economy. This weight can be measured by its share of exports or national imports. Country $\mathrm{i}$ therefore constitutes $\alpha \mathrm{i} \%$ of the country's trade with $\sum_{i=1}^{n} \alpha i=1$

Call Ei the nominal bilateral exchange rate of the local currency with that of the country i. The nominal effective exchange rate is given by the following weighted geometric mean:

$$
E=\left(E_{1}\right)^{\alpha_{1}}\left(E_{2}\right)^{\alpha_{2}} \ldots \ldots\left(E_{n}\right)^{\alpha_{n}}=\prod_{i=1}^{n}\left(E_{i}\right)^{\alpha_{i}}
$$

The price index $\mathrm{P}^{*}$ is calculated in the same way. If $\mathrm{Pi}$ is the price index of country $i$, then:

$$
P *=\left(P_{1}\right)^{\alpha_{1}}\left(P_{2}\right)^{\alpha_{2}} \ldots \ldots\left(P_{n}\right)^{\alpha_{n}}=\prod_{i=1}^{n}\left(P_{i}\right)^{\alpha_{i}}
$$

The expression of the real effective exchange rate $\lambda p$ is obtained (Banque de France, 1998) by substituting (A2) and $(\mathrm{A} 3)$ in $(\mathrm{A} 1)$ :

$$
\lambda_{P}=E \cdot \frac{\left(E_{1} P_{1}\right)^{\alpha_{1}}\left(E_{2} P_{2}\right)^{\alpha_{2} \ldots . .\left(E_{n} P_{n}\right)^{\alpha_{n}}}}{P}=\frac{\prod_{i=1}^{n}\left(E_{i} P_{i}\right)^{\alpha_{i}}}{P}
$$

\section{Characterization and Definition of Agricultural Formations}

"Family farming encompasses all family-based farming activities in relation to many aspects of rural development. Family farming allows for the organization of agricultural, forestry, fisheries, pastoral or aquaculture production, which, under the management of a family, relies mainly on family labour, both men and women" (FAO 2013). Thus, family farming refers to an agricultural practice in which the family makes decisions about the production and organization of work and has a large part of the means of production. Work on the farm is essentially carried out by family members, but employees can contribute additional labor at certain seasons of the year (Chambost 2014). 
Contrary to what is accepted, it does not refer to the size of the company (Losch and Fréguin-Gresh, 2013) or technological level, market orientation or research and profit maximization. Indeed, some families use a large part of their production to feed themselves while others sell all of it. In addition, according to the principle of saving in size and the law of decreasing returns, a small farm may be more profitable than a relatively larger-sized farm if it produces to a minimum (Kay et al., 2012) of its average costs.

In addition, corporate agriculture or agricultural entrepreneurship should not be confused with the farming enterprise (employers' form), the latter being included in the first. Indeed, enterprise agriculture is an autonomous economic unit combining factors of agricultural production, producing for the sale of agricultural goods and services and distributing income in return for the use of factors. Corporate agriculture is divided into two forms of agricultural organization: the family farming enterprise and the farming enterprise (employers' form). The employer's form is distinguished from that of the family by the separation of ownership and management functions, that is, when the managers are not members of the shareholder family, and ownership and control such as lack of physical proximity to non-executive shareholders and the absence of family members on the board of directors. According to Allouche et al. (2007), differentiation can be made in the performance and financing policies of family and non-family businesses. According to these authors most studies conclude that family businesses are characterized by higher performance than non-family businesses. The report was made in stock markets by Anderson and Reeb (2003), Villalonga and Amit (2004). The best economic and financial performance of family businesses has been confirmed by Allouche and Amann (1995), McConaughy et al. (1998), Lee (2004), Sraer and Thesmar (2004). The reasons are that family businesses are managed more efficiently than non-family businesses because of reduced control costs and incentives for managers, long-term intergenerational orientation, the homogeneity of the value system in these (Allouche et al., 2007).

However, Allouche et al. (2007) report that published studies generally conclude that family businesses are characterized by a lower reliance on indebtedness, due to the priority given to sustainability and family control, motivated by the desire to transfer the company to future generations, which leads to a strong aversion to risky strategic and financial decisions.

Finally, Belieres et al. (2014) based on the place occupied respectively by the family organization and the methods of control of productive capital have elaborated the typology of the main forms of organization of agriculture. They clearly distinguish between family farming and entrepreneurial agriculture.

Table 2 Typology of the main forms of organization of agriculture

\begin{tabular}{|c|c|c|c|}
\hline & Agricultural crops & \multicolumn{2}{|c|}{$\longleftrightarrow$ Family farming } \\
\hline & Entrepreneurial Shapes & Employer Forms & Family forms \\
\hline Workforce & Exclusively employed & $\begin{array}{l}\text { Mixed, presence of } \\
\text { permanent employees }\end{array}$ & $\begin{array}{l}\text { Family dominance, no } \\
\text { permanent employees }\end{array}$ \\
\hline Capital & Shareholders & $\begin{array}{l}\text { Family or family } \\
\text { association }\end{array}$ & Family \\
\hline Management & Technical & Family / Technical & Family \\
\hline Consumption & Not applicable & residual & Partial self-consumption \\
\hline Legal status & $\begin{array}{l}\text { Public limited company or other forms } \\
\text { of partnership }\end{array}$ & $\begin{array}{l}\text { Operator status, associative } \\
\text { forms }\end{array}$ & Informal or Operator Status \\
\hline Property Status & $\begin{array}{l}\text { Property or property } \\
\text { Indirectly formal }\end{array}$ & Indirect, formal or informal & roperty or tenure \\
\hline
\end{tabular}

Source: Belieres et al. 2014

\section{The Transitional Constraints of Agricultural Formations}

The constraints faced by agricultural finance, in order to stimulate the change in the farming system, are technical and political.

\section{Technical Constraints}

The question of financing: Agricultural finance is expected to provide all the financial resources, both internal and external, available to an agricultural enterprise (company, independent or non-profit making) and giving it the means of action necessary to carry out its activity (Anonymous, 2016). From the point of view of this definition there are two main sources of economic activity: external sources (subsidies and credits) and internal sources (capital and self-financing).
Any investment in the company and any financing of its activities is based on the prospect of some future profitability (Depallens, 1971). Thus, profitability is the goal of investments and financing. Mbaya, (2007) define profitability as the capacity of invested or invested capital to provide income expressed in financial terms. Profitability is therefore seen as the ability of an investment to pay its shareholders. It is then restrictive to judge the performance or survival of a company in a competitive environment. Based on this observation, some authors are interested in the economic role of the company, ie its ability to transform its capital into income, regardless of their origin. They define profitability, as the ratio realized between the profits and the capital committed to arrive at this result (Kay et al., 
2012). Agricultural finance raises two types of constraints. From the financial point of view, agricultural speculation with low agricultural value is not in its centre of interest. To minimize the risk of unpaid financing will be increasingly oriented towards profitable agricultural businesses that is to say that have a return above the interest rate. This excludes most agricultural crops whose profitability is below $12 \%$ (bank interest rate). The risk is reinforced by the climatic hazards and the allocative inefficiency of the factors of production. The second hurdle is at the level of producers whose objective is not financial profit. For the latter, whatever the interest rate, they can find no one to contract a bank loan as long as the factors of production at their disposal allow them to achieve the production necessary for their subsistence.

The solution would be to set up a financing system adapted to agrarian conditions in Burkina Faso and develop awareness campaigns among farmers, on the existence of leverage and the importance of profit in the process of enlistment and to sustain the company, in order to boost agriculture.

Lack of farm accounting: One of the major shortcomings in Burkina Faso's agriculture is the lack of accounting to bring out the Intermediate Management Balances (IBM). But without the IMB, it is impossible to pronounce on the performance of a company. The most important IMB used are among others: Net Farm Income; Rate of return on farm assets; Rate of return on farm equity; The operating profit margin ratio; and Earnings Before Interest, Taxes, Depreciation and Amortization (RAIIDA).

However, the absence of reliable accounting, the multiproduct nature of farms, and the fact that agricultural assets are valued at their market value and not at home, lead farm managers to reason in terms of profitability rather than "rentability". For this reason, most valuations are limited to the calculation of net farm income. This approach seems more appropriate for family farms since most of them do not have accounting records and do not aim at financial profit but economic profit. There is thus a confusion between household income and business assets that makes the financial profit approach inappropriate. The solution would be to train farmers in bookkeeping so as to bring out clearly the IBM indicators needed for any conventional financial support.

Very low opportunity costs of labour and land: The opportunity costs of the main factors of production of family farming are low. Indeed, these factors that are land, work, and water are almost free. But the lack of equipment and machines to exploit them makes their productivity very low. On the other hand, agriculture's dependence on rainwater means that farmers are underutilizing the productive potential, because a large investment in agricultural equipment would lead to their immobilization, there is only one rainy season. Of the 9 million hectares of exploitable agricultural land, about 4.9 million hectares are cultivated each year, including $10.5 \%$ of potentially irrigable land (Burkina Faso, 2015). As long as the irrigation system is not developed to increase the intensity of use of the capital invested, agricultural production will remain extensive in order to exploit the maximum of land rent in the short term.
In addition, human capital needs to be improved (more than $90 \%$ of family farmers are illiterate) in order to boost productivity, opportunity costs and labour mobility. Since work has a low value, its demand is elastic because it is the applicant who determines his price. The consequence is the absence of an agricultural labour market because the opportunity cost of working for the other is very high rather than working for oneself. This is why family farms are more successful than agricultural enterprises in rural Burkina Faso.

Increase in the opportunity cost of fixed capital: On the other hand, the opportunity cost of depreciable and financial assets is very high. For this reason, average production costs are high and increasing due to the fact that there is only one agricultural production cycle in Burkina Faso. The opportunity cost of a heavy investment in agriculture is high compared to other urban real estate or the short-term and medium-term rent is high. Ouedraogo's work in 2003 on the results of agribusiness operating accounts shows a loss on the first two crop years. The economic profit varied from -5,802,750 FCFA to $-256,750$ FCFA. According to Ouedraogo (2003), the size of the deficit is not related to the size of the farms in terms of the investments in the first and second year which increase the average operating costs because of the annual depreciation and the productivity of agricultural activities. This partly justifies the moderate investment in the actors' agriculture. In addition, makes the investment depends on the payback period. The longer it is, the lower the investment and the shorter it is, the more important it is. Banks are also interfering with investment choices by financing high value-added crops such as vegetables and fruits at the expense of cereal crops to reduce the financial risk associated with the duration of the return on investment (Sogué and Akcaoz, 2017). But they refuse to finance the main speculation of the family farms that constitute the main base of food in Burkina Faso. The transition to corporate agriculture is synonymous with abandoning the exploitation of its crops. This may pose food security problems if cash crop payments do not cover the costs of importing grain products. To improve agricultural profitability, it is imperative to move towards specialization and agricultural concentration, promote value chains, and increase the rotation of agricultural assets through irrigation and the use of improved varieties.

The opportunity cost of physical capital is supplemented by the financial cost. Indeed, rural savings are low to constitute the amounts needed to finance agriculture. In addition, according to Christen and Anderson (2013), financial institutions seeking to work in rural areas face many constraints, including inadequate infrastructure, fragmentation of demand, price and yield risks (Sogué and Akcaoz, 2017), and limited warranties. This results in the absence of banks in rural areas. They are replaced by microfinance institutions that offer many similar funds such as short-term working capital with frequent repayments, sometimes unsuitable for long-term agricultural activities or seasonality of cash flow.

The situation of agriculture is complicated in the developing countries where in addition to these technical constraints there are those of institutional orders. 


\section{Institutional Constraints}

Land tenure: Insecurity remains a major obstacle to investment as evidenced by the proportion of exploited land (less than $55 \%$ out of a total of 9 million ha). Rural land in Burkina Faso is characterized by a juxtaposition of customary and modern land rights (Ki-Zerbo, 2004). The dualism of land tenure standards complicates the process of establishing land titles that would serve as a guarantee for banks to obtain credit. However, in order to accompany and ensure agricultural investment, the Burkina Faso legislator drafted the Agrarian and Land Reform Act (ALR) in 1984 revised in 1991, 1996 and 2012 in order to control land insecurity but is not effective in solving the problems of securing land tenure because traditional law resists to the modern law and makes it non-operational.

For Burkina Faso (2007), 20 years after the promulgation of the ALR, the question of land tenure security and the stabilization of producers' rights is still posed, with the result that conflicts are increasingly frequent and more frequent. These pitfalls prompted the government to regain control of the issue in 2007 by announcing a National Policy for Rural Land Security (NPRLS), which resulted in the adoption in June 2009 of a rural land tenure law Program Millennium Challenge Corporation (MCC) called "Compact" is an application of it. For some, the resolution of the constraints linked to the application of ALR requires a participative approach in the process of elaboration of the NPRLS in order to know the realities and the realities expectations of the different rural actors and to take into consideration the dynamics in progress and mainstreaming the major policies underway in Burkina Faso (poverty alleviation, rural development decentralization strategy, etc.); to build a national land consensus based on the opening of a national land debate, involving all key rural actors, such as rural producers, the State, local authorities and the private sector (Burkina Faso 2007). The integrated approach was favoured during the drafting of the NPRLS in August 2007.

But to this day the land problem remains because the laws have been simply voted to legalize a practice of expropriation of rural land by agribusiness men that existed since long time rather than restore the right of the peasants. Therefore, the latter view these laws as a sort of duplicate market on the part of the legislator and the alternative proposed by Burkina Faso (2007) and reiterated by the law 034-2009 rural land tenure thus consists in accompanying the development of new institutions. The legitimacy of its new institutions will result, on the one hand, from the accompaniment of their construction on the basis of pre-existing institutions; it will also result from their operation on the basis of democratic principles of natural resource management. Customary authorities are taken into account and involved in supporting the effectiveness of legitimate local institutions. "Conflict management is an integral part of rural land tenure security" (Burkina Faso 2009). In addition, Law 034-2009 in support of the NPRLS will officially recognize customary rights (which can be formalized through land ownership certificates and loan agreements) and transfer the management of land to rural communes. It also offers interesting tools for managing natural resources through local land charters, which are the result of negotiations between local populations and can now be officially recognized by the State services and local authorities. Domaniality or State ownership has been abandoned and land is now divided into three distinct domains: the domain of the State, the domain of individuals and the domain of local authorities (Burkina Faso, 2009). The ultimate solution to agricultural investment will be to speed up the process of setting up local land structures (villages and communes) in accordance with Law No. 034, on land tenure in rural areas.

\section{Competitive Constraints Related to The FCFA's Fixed} Exchange Rate Regime

The CFA franc affects the competitiveness of our agricultural products because of the fixed exchange rate and the high purchasing power parity of the currency (Nubukpo 2017).

Table 3 Terms of exchange*

\begin{tabular}{l|rrl}
\hline Years & IVI & EVI & CEP \\
\hline 2005 & 108 & 92 & 0.85 \\
2006 & 122 & 96 & 0.79 \\
2007 & 125 & 103 & 0.82 \\
2008 & 131 & 86 & 0.66 \\
2009 & 139 & 116 & 0.83 \\
2010 & 133 & 115 & 0.86 \\
2011 & 176 & 147 & 0.84 \\
2012 & 207 & 155 & 0.75 \\
2013 & 233 & 236 & 1.01 \\
\hline
\end{tabular}

Source: FAOSTAT, 2017; IVI: Import Value Index (2004-2006 = 100); EVI: Export Value Index $(2004-2006=100)$; CEP: The competitiveness of export prices

The terms of trade indicator is a complex piece of information analysed and clearly shows a deterioration in the terms of trade of agricultural products over the period 2005-2013 (Table 3). We have used the price indices import and export of the FAOSTAT (2017) to calculate the terms exchange of agricultural products Burkina Faso over the period 2005-2017. Moreover, the report on the competitiveness of the WAEMU economies in 2012 of ECOWAS (2013) reveals that Burkina Faso's foreign penetration rate has increased by 0.6 point. This trend reflects a decrease in the domestic market share acquired by local companies, and therefore a net loss of competitiveness.

This is partly due to the fact that the fixed exchange rate of the CFA franc appreciates relatively in the foreign exchange markets due to the continued decline of the US dollar. All other things being equal, this exchange rate distortion leads to an increase in the prices of agricultural products exported, while those of imported products fall (Arnaudin, 2015). The valuation of the CFA franc acts as an implicit export tax, restricting the access of our agricultural products to foreign markets. At the same time, its overvaluation constitutes an import subsidy. The immediate consequence is the deterioration in the price competitiveness of our agricultural products. It is necessary to move towards flexible exchange rate regimes in order to eliminate the cost of money on the prices of exported agricultural products. Because the long-term loss of the price competitiveness of our agricultural products will lead to a slowdown in investment or disinvestment in agriculture. This will undermine all efforts to achieve the agricultural transition. 


\section{Conclusion}

While in theory the transition from family to business is feasible and an asset to improve agricultural productivity, fighting against food insecurity and poverty in rural areas, this is not without insurmountable constraints. Among these constraints are those of technical and institutional orders. The technical constraints are related to the lack of labour market accounting, the inadequacy of the traditional financing system to rural realities, the opportunity costs of highly depreciable assets, the arbitrage between high valueadded cultures and fight against food insecurity.

Regarding institutional constraints, it is the precarious tenure and distortions that exchange rates exert on the price competitiveness of agricultural products. On the other hand, while technical constraints are relatively less complicated to overcome institutional constraints, they seem insurmountable at present for the juxtaposition of modern and customary law over land. And we are far from finding a compromise for the removal of land disputes and the establishment of rural land titles.

In order to solve technical problems, the state and agricultural extension agents must work to direct agricultural production to the profit-orientation and not to consumption alone. To do this, we must strengthen the human capital of farmers, train them to keep the books, promote value chains. The state must work towards the specialization and the progressive concentration of agricultural exploitation in order to highlight the economic profitability, the leverage effect of the indebtedness and the financial profitability of the capital. In addition, public partners, credit institutions and farmers must work in synergy to resolve certain financial constraints such as the very high debt ratio which reduces the leverage effect and increases the risk of non-payment. An intensification of rainfed agriculture coupled with a system of off-season irrigation will increase the rotation of agricultural capital thus its profitability.

In terms of recommendation for institutional constraints, land security must be guaranteed in order to allow private investment. To this end, it is necessary to speed up the process of setting up local land structures (villages and communes) in accordance with Law No. 034 on land tenure in rural areas. Finally, the exit from a fixed exchange rate regime generated gains in competitiveness for agricultural products.

\section{References}

Anonymous 2016. Financement de l'entreprise. http://www.1819.be/fr/financement-de-lentreprise/lecapital/ quentend-par-capital. [Accessed 16 February, 2018]

Allouche J, Amann B, Garaudel P. 2007. Performances et caractéristiques financières comparées des entreprises familiales et non familiales : le rôle modérateur de la cotation en bourse et du degré de contrôle actionnarial, Journal de l'Entreprise Familiale, Octobre 2007.

Allouche J, Amann B. 1995. Le retour triomphant du capitalisme familial, in De Jacques Coeur à Renault: Gestionnaires et Organisations, Presses de l'Université des Sciences Sociales de Toulouse.

Anderson RC, Reeb DM. 2003. Founding Family Ownership and Firm Performance: Evidence from the S\&P 500, Journal of Finance, 58(3): 1301-1328.
Arnaudin S. 2015. économie.gouv.fr, le portail de l'économie, 8 décembre 2015. http://www.sesarnaudin.com/2015/12/ notionscompetitivite-prix-et-hors-prix.html [Accessed 16 February, 2018]

Banque de France, 1998. Bulletin de la banque de France $-\mathrm{n}^{\circ} 60-$ décembre 1998

BCEAO. 2013. Rapport sur la compétitivité des économies de l'UEMOA en 2012

Belieres JF, Bonnal P, Bosc PM, Losch B, Marzin J, Sourisseau JM. 2014. Les agricultures familiales du monde: Définitions, contributions et politiques publiques. Octobre 2014.

Burkina Faso 2007. Politique nationale de sécurisation foncière en milieu rural. http://www.onf-bf.org/sites/default/files/ field/slideshow/PNSFMR.pdf [Accessed 16 February, 2018]

Burkina Faso 2009. Loi n 034-2009/AN portant régime foncier rural. Adoptée par l'Assemblée Nationale le 16 juin 2009.

Burkina Faso, 2017. 20ème édition de la Journée nationale du Paysan. Thème: «La Journée Nationale du Paysan, 20 ans d'existence : Bilan et perspectives $»$. Document synthèse.

Chambost P. 2014. Agriculture familiale: de quoi parle-t-on? Les Nations Unies ont proclamé 2014 années internationales de l'agriculture familiale.

Christen PR, Anderson J. 2013. Segmentation of Smallholder Households: Meeting the Range of Financial Needs in Agricultural Families. No. 85, April 2013.

Depallens G. 1971. Gestion financière de l'entreprise. Revue économique, 22(3): 551-552;

FAO. 2013. Why a FAO. Financement agricole : Un puissant outil de contribution à la sécurité alimentaire des populations. Desjardins développement International, Novembre 2010.

FAOSTAT. 2017. http://www.fao.org/faostat/en/\#data/TI [Accessed 16 February, 2018]

Global Water Patershisp West Africa. 2015. Rapport Final de la Consultation Nationale sur l'eau, la sécurité alimentaire et la nutrition: Burkina Faso

Godet L. 1994. Dynamique des coopératives agricoles et politiques économiques au Burkina Faso. Centre ORSTOM de Ouagadougou, Programme de recherche: "politiques et développement agricoles et agro-industriels au Burkina Faso », Rapport de stage, Document n 3, Avril 1994.

Kay RD, Edwards WC, Duffy PA. 2012. Farm Management. Seventh edition, international Edition, McGraw Hill Higher Education (Asia), for manufacture and export.

Ki-Zerbo F. 2004. Les femmes rurales et l'accès à l'information et aux institutions pour la sécurisation des droits fonciers. Etude de cas au Burkina Faso.

Lee J. 2004. The Effects of Family Ownership and Management on Firm Performance, SAM Advanced Management Journal, autumn, 46-53.

Lesaffre D. 2000. A propos de l'offre et de la demande du financement du monde rural en Afrique de l'Ouest, Projet d'Utilisation des Fonds Suisses (PUF), Lomé.

Losch B, Fréguin-Gresh S. 2013. Quelles agricultures face aux défis des transitions africaines? Le small-scale versus large-scale en débat. Cahiers Agriculture, 22 (1): 10-15. doi:10.1684/agr. 2012.0573.

Mbaya RG. 2007. L'entreprise et sa rentabilité. Université de Lubumbashi, RDC - licence en sciences de gestion. https://www.memoireonline.com/05/10/3521/Lentreprise-et-sarentabilite.html [Accessed 16 February, 2018]

McConaughy DL, Walker MC, Henderson GV, Mishra CS. 1998. Founding Family Controlled Firms: Efficiency and value, Review of Financial Economics, 7(1): 1-19.

Mishra CS, McConaughy DL. 1999. Founding Family Control and Capital Structure: The risk of loss of control and the aversion to debt, Entrepreneurship Theory and Practice, 23(4): 53-64.

Nicolas G. 1965. Problèmes de technique comptable agricole. In: Études rurales, n 16, pp. 5-65

Niyongabo E. 2008. Défis du financement agricole et rural, rôle pour la microfinance et implications pour les politiques publiques en Afrique subsaharienne. Pistes de recherche basées sur le cas du Burundi.

Nubukpo K. 2017. Je ne partage pas l'analyse de ceux qui pensent que le franc CFA s'inscrit dans une sorte de complot français contre l'Afrique. http://www.financialafrik.com [Accessed 12 April, 2017] 
Ouédraogo B. 2010. Améliorer le système de financement de l'agriculture: http://ipsinternational.org/fr/_note.asp?idnews $=5666$. $[$ Accessed 16 February, 2018]

Ouedraogo M, Ouedraogo S, Yelemou CP, Diallo B. 2011. Analyse de la compétitivité du riz local au Burkina. Résumé N 5- 2011 12. Décembre 2011

Ouedraogo M. 2003. 'Les nouveaux acteurs et la promotion des activités agro-sylvo-pastorales dans le sud du Burkina Faso: Faux départ ou inexpérience ?', IIED, dossier $n^{\circ} 118$.

Ouestafnews. 2009. Burkina Faso: Ecobank rachète la BACB pour devenir la première banque du pays. Jeudi 22 Janvier 2009.

Sogué B, Akcaoz H. 2017. Risk Management in Agriculture: Examples from Some Countries. Turkish Journal of Agricultural Economics. 23(1): 69-83
Sraer D, Thesmar D. 2004. Performance and Behavior of Family Firms: Evidence from the French stock market, CEPR Discussion Paper No.4520. http://ssrn.com/abstract=593826. [16 February, 2018]

Touré O, Seck SM. 2005. Exploitations familiales et entreprises agricoles dans la zone des Niayes au Sénégal. International Institute for Environment and Development. Programme Zones Arides. Dossier no. 133. Mars 2005.

Villalonga B, Amit R. 2004. How Do Family Ownership, Control, and Management Affect Firm Value? EFA 2004 Maastricht Meetings Paper No. 3620.

Wampfler B, Lapenu C. 2002. Le financement de l'agriculture familiale dans le contexte de la libéralisation. Quelle contribution de la microfinance? Séminaire International de Dakar,CIRAD/CERISE. 